\title{
Digital Natives? New and old media and children's outcomes
}

Deploying the term "digital natives", Marc Prensky (2001) theorized that growing up in a world mediated by digital technologies alters the way in which "millenials" (Howe \& Strauss, 2000), or the "net generation" (Tapscott, 1998), undertake cognitive and information processing. As "native speakers of the digital language of computers, video games and the internet" (Prensky, 2001), they are held to be active, experiential learners, natural multitaskers, utilising a range of digital devices and platforms simultaneously to drive their own informal learning agendas. Implicit in the debate thus generated is a critique of current schooling practices and the competency of adult teachers ("digital immigrants"), to mediate children's literacy development. The thesis explicitly promotes multimedia or games-based learning (Prensky, 2001; Gee, 2003) over outdated "linear" media (books, television), and text-based resources.

Critics of the evidence base behind the digital natives thesis (Buckingham, 2006; Jenkins, 2007; Bennett, et. al, 2008; Hague \& Williamson, 2009; Helsper $\&$ Eynon, 2010) argue that it ignores differences in access to, time spent with, and contexts of use of, a wide range of media technologies and platforms, related to the child's age, and socio-economic status, and cultural resources within families. Large representative surveys of young people's digital and non-digital media (Lenhart et. al, 2005) show significant internet activity, but this varies according to age and income variables. A recent review of evidence (Bennett et al., 2008) concludes that there are a "significant proportion of young people who do not have access or technology skills predicated by proponents of the digital native idea" and the thesis threatens to focus educators' attention on "technically adept" students. Moreover, identifiable differences associated with developmental stages of infancy, early childhood, middle childhood and adolescence complicate claims about universal learning styles and skills with new media platforms: for example, developing visual, auditory and 
memory capacities (Anderson \& Hanson, 2010). In addition, the multitasking that purportedly characterises digital natives has been associated with concentration lapses and cognitive overload due to effects of competing stimuli (Rubinstein, et al., 2001). The unproblematic assumption that games-based learning is preferable to text-based learning has also been contested. While evidence exists for the benefits of modified game-based approaches (Dede, 2005), there has been insufficient research into game development for deep learning (Bennett et al., 2008; Moreno and Mayer, 2005). Consideration of theories of new media and new literacies further contextualise such debates.

\section{New media, new literacies}

The digital natives thesis posits a radical discontinuity between the environment shaped by digital media and older media: a "singularity" which "changes things so fundamentally that there is no going back" (Prensky, 2001). Conversely, Manovich (2003) conceptualises new media as a hybrid mix of existing cultural logics and conventions and the conventions of software. Other historians of technology emphasise the continuities between older media platforms and "new" media that challenge, and sometimes, eventually, completely displace them (Silverstone, 1999; Livingstone, 2002). Rather than a radical discontinuity, much recent theory articulates a "convergence" of media forms (Spiel, 2004; Jenkins, 2006).

Alongside the notion of new and converged media, educationalists have evolved theory concerning new and multiliteracies (Coiro et al., 2008; Kress, 2003; Martin \& Madigan, 2006). Traditional literacy is taken as the ability to read and write in the shared language of a culture (Hague $\delta$ Williamson, 2009). Multiliteracy theory suggests that there is a plurality of literacies, different technological platforms and environments may require different constellations of literacy skills (Cope \& Kalantzis, 2000). In an extensive review of research literature, digital literacy is defined as "critical thinking in the context of technology use" of which there are two 
components "digital skills and critical thinking skills" (Newman, 2008: 5). Summing up the focus of this research trajectory on outcomes for children, digital literacy is linked with the goal of social participation: "the knowledge, skills and understanding that are required to be involved socially, culturally, politically, and economically in everyday life" (Hague \& Williamson, 2009: 3). One of the goals of our paper is to examine the influences of "old" and "new" media technologies on the development of early foundations for generalisable literacy skills, and their relation to children's outcomes.

\section{Pages and screens, old and new}

There has been little study of the longitudinal effects of children's new media use on language acquisition, literacy and school performance. However, there a voluminous literature on older screen and page media (television and reading) on children's learning. While clear links have been found between the amount of time children spend reading and academic achievement (Hofferth \& Sandberg, 2001), the literature on television suggests that mediating variables such as parental education/socioeconomic status (Brown et al., 2008; Bianchi \& Robinson, 1997; Hofferth \& Sandberg, 2001; Baxter \& Hayes, 2007); types of content (educational or commercial), age at which educational content is viewed by disadvantaged children (Bickham et al.. 2001; Anderson et al, 2001), may be at least as important as measures of simple time use.

Negative impacts of television on children's cognitive development and educational achievement have been associated with: displacement of cognitively more valuable activities, especially in infancy (Anderson $\delta$ Pempek, 2005) and early childhood (Schmidt \& Anderson, 2007); disruption of concentration (background television) (Foehr, 2006; Rideout \& Hamel, 2006); reduced parental mediation/guided interaction enabled by coviewing (Kirkorian, et al. 2008; Linebarger \& Vaala, 2010), sleep disturbances (Paavonen et al., 2006) or increased hours of viewing occasioned by the presence of TV in child's bedroom (Vandewater et al., 
Copyright 2011 A ustralian Council for Educational Research. T his article may not exactly replicate the final version published in A ustralian Journal of Education. It is not a copy of the record. Final and authorised version first published in A ustralian Journal of Education in Vol. 55(2), published by the A ustralian Council for Educational Research.

2005). It has been argued that excessive hours of viewing by itself leads to overconsumption of inappropriate types of content (Hancox et al., 2005; Millwood Hargrave \& Livingstone, 2006). Evidence suggests that digital natives' digital media use does not replace but operates in tandem with older forms (Roberts \& Foehr, 2008), such as print. Studies of adult populations, including six national time-use diary studies (Robinson $\mathcal{E}$ Martin, 2010), find higher amounts of reading among internet and IT users. US studies have also correlated home computer ownership and internet use with academic performance, particularly reading performance (Jackson et al., 2006; Roberts et al., 2005). All "new" or digital media, however, may not be alike in their impacts on educational achievement, with time spent by 8-18 year olds playing video games being negatively associated with school performance, measured by grade point average (Roberts et al., 2005). Thus, while it has become common to celebrate children's engagement with digital media in their recreational activities (such as video gaming, social networking sites, video, image and music sharing, music/image editing and animation using online and other resources), this might not necessarily equate with the skills and competencies associated with either traditional or digital literacy (Hague 8 Williamson, 2009). Prior acquisition of text-based literacy (whether texts are distributed by print or screen "page") may be crucial for the critical thinking skills associated with all "new" literacies.

\section{Research Questions}

This paper tests the hypothesis that access to digital technology alone guarantees development of crucial literacies and that "new media" are more critical in the developmental process than older electronic and print media (the "digital natives" thesis). Secondly, that the context of access and mediation provided by parents (as "digital immigrants") are no longer crucial in guiding the acquisition of foundational literacy skills, including ICT literacy. There is very little research on young children and new media. In the absence of 
Copyright 2011 A ustralian Council for Educational Research. T his article may not exactly replicate the final version published in A ustralian Journal of Education. It is not a copy of the record. Final and authorised version first published in A ustralian Journal of Education in Vol. 55(2), published by the A ustralian Council for Educational Research.

large-scale empirical data some writers have assumed that new media will resemble television in its effects of on the development of a child's language abilities. The research presented in this paper uses an longitudinal data to disentangle the effects of access, context, time "exposed" to different media, including reading, on the child's language skills at different stage of their development, while controlling for family socio-economic resources.

\section{Methods}

This paper uses data from the first three waves of the Longitudinal Study of Australian Children (LSAC) (Soloff, Lawrence \& Johnstone, 2005). Briefly, LSAC is a national longitudinal study which follows two Australian cohorts born in 1999 and 2003 at two year intervals starting in 2004. The 2003 cohort $(n=5107)$ and the 1999 cohort $(n=4983)$ were aged 0-1 and 4-5 years respectively in 2004 .

Data were obtained using a combination of a face-to-face interview, self complete questionnaires, a child's time use diary; and, for the 1999 cohort (collected in 2008), a teacher report. Additional data about the stocks of digital devices, and the monitoring and regulation of digital technologies, were collected in a supplementary postal survey (Wave 2.5, 2003 cohort $\mathrm{n}=3246 ; 1999$ cohort, $\mathrm{n}=3252$ ) in 2007.

Sample representativeness at Wave 1 was established by comparison with the Australian population using 2001 Census data. Correspondence across a wide range of demographic measures was high but the sample slightly over-represented highly educated mothers (around 10\% more with postsecondary education) while single parents, non-English speaking families, and families living in rental properties were all slightly under-represented (Soloff, Lawrence, Misson, \& Johnstone, 2006). Analyses of sample losses from Wave 1 to Wave 3 showed socioeconomic attrition biases with lower retention for children with less educated parents, living in rental properties and from non-English speaking backgrounds (Sipthorp \& Misson, 2009). 
Copyright 2011 A ustralian Council for Educational Research. T his article may not exactly replicate the final version published in A ustralian Journal of Education. It is not a copy of the record. Final and authorised version first published in A ustralian Journal of Education in Vol. 55(2), published by the A ustralian Council for Educational Research.

\section{Measures}

Outcome measures (Wave 3)

For both cohorts language ability was measured at Wave 3 using a specially adapted short form of the Peabody Picture Vocabulary Test-Third Edition (PPVT-lll). The PPVT measures receptive vocabulary and is frequently used to measure language acquisition in the early years (Wright, et al, 2001).

For the 1999 cohort the Academic Rating Scale (ARS) was also used. The ARS is a teacher rated measure of the study child's academic performance at school using a 9 item scale. Teachers scored children on the following items, whether the study child: conveys ideas clearly when speaking; uses various strategies to gain information using print materials; reads fluently; reads grade level books (fiction) independently with comprehension; reads and comprehends informational text; composes multi-paragraph stories/reports; rereads and reflects on writing, making changes to clarify and elaborate; makes editorial corrections when reviewing a written draft; and uses the computer for a variety of purposes. The ARS scale showed good reliability (Chronbach's $\square=0.94$ ).

Explanatory variables (Waves 1-3)

Independent variables of interest were (1) a cross-wave measure of the time spent in media use and (2) measures of parental efforts to manage circumstances of the study child's use of media.

Time spent reading, viewing television or using a computer were each assessed using a "light" time-use diary. A responsible adult, commonly the mother, completed two 24-hour diaries of the child's activities, for a randomly assigned weekday and weekend day. Synthetic daily estimates (hours per day) were calculated ([weekday time x 5] + [weekend day time $\mathrm{x}$ $2] / 7 / 60$ ).

The longitudinal patterns of media use over three waves were established using a two-step process. The first step organised the synthetic weekly 
estimates for reading, television viewing and computer use into three equal parts (tertiles). The first tertile spent the least time, the third tertile the most time, while the second tertile was intermediate. In the next step, children were then classified into one of three groups, consistent low use, mixed use and consistent high use.

Parents were also asked (in Wave 2.5 collected in 2007) a range of questions on their child's access to digital devices and parental mediation of child's use (context). Parents provided information about whether the study child had a television, computer or internet access in their bedroom, whether they had a computer in the home, whether they had internet access in the home and whether the child had an electronic games system (e.g. Gameboy, Nintendo, Playstation, X-Box). Parental mediation was assessed using four items for the 2003 cohort and two items for 1999 cohort. These were (1) whether the child turns the television on by themselves "often/sometimes" versus "rarely/never" (2003 cohort only); (2) whether the television is "always/often" versus "sometimes/rarely/never" on while no-one is watching (2003 cohort only); (3) whether a parent "always/often" versus "sometimes/rarely/never" watches television with the child (2003 cohort only); (4) whether the parent wished the child would spend less time watching television, DVDs or playing computer games (1999 cohort coded only); and (5) how "easy" or "difficult" the parent finds it to manage the child's watching television, videos DVDs (both cohorts).

\section{Controls (Wave 1)}

Previous research suggests that the family's socio-economic resources and the mother's education are regularly found to have a strong influence on both media use and outcomes. These were controlled for in this study. Family resources were measured in bands for gross income (e.g. a weekly income of $\$ 1-49, \$ 50-\$ 99$ etc). The midpoint of each band was used to represent the dollar value of this band. Income was adjusted for family size and equivalised household gross income was calculated by dividing the gross income estimate by the square root of the number of people in the household. Mother's education was measured in years. 


\section{Data Analyses}

The sample was restricted to those participants with two days of good quality diary data from at least two waves and for whom there was complete data on digital devices and regulation (Wave 2.5 postal survey) and teacher academic ratings (Wave 3 for the 1999 cohort). The final analytic sample for the 2003 cohort was 2,335. For the 1999 cohort the final sample for the analysis of effects on language acquisition (PPVT-III) was 2,233 and for teacher's rating of their academic performance (ARS) was 1,892 .

Longitudinal associations between media use (Waves 1-3) and parental practices (Wave 2.5) and the outcome variables (Wave 3) were determined for each of the cohorts using linear regression after adjusting for equivalised household income and mother's education (Wave 1). Analyses were implemented using Stata 8.2, taking into account the complex survey design.

\section{Results and Discussion}

Table 1, below shows the results of the regression analysis of the Peabody Picture Vocabulary Test (PPVT) scores for the younger (2003) cohort. The model presented here tests the effects of access, context, time "exposed" to electronic media and time spent in reading while controlling for family resources on the child's vocabulary at age four. Family resources consist of household income, adjusted for family size and the parents' stocks of "social capital" (proxied by the mother's education in years) (Bourdieu, 1968).

Children allocating sustained time to the oldest media (print) exhibit significantly higher PPVT scores than those with a consistently low investment of time, which is consistent with earlier studies (Anderson et al., 1988).

Access to new and older electronic media also matters. After controlling for the child's time spent reading, having access to the internet is 
positively related to verbal abilities. In contrast, the results for a television in the child's bedroom was significantly (P-value $<0.005)$ associated with poorer vocabulary at age four. The other measures of the context of media use also show a significant effect, in the expected direction. Having the television running while no one is in the room, indicating little attempt to manage the child's viewing (Wiecha et al., 2001), lowers verbal abilities. Co-viewing, in contrast, heightens them. Parental management of the child's game-playing seems to have no significant influence. At this early age, the context that parents create for television usage appears to be the major determinant of the child's receptive vocabulary.

As previous research suggests (Garrett et al., 1994; (Rowe et al., 2005; Duncan \& Brookes-Gunn, 1997), high income security and stocks of social capital powerfully promote language acquisition. The findings presented in Table 1 show a significant $(\mathrm{P}$-value $<0.001)$ positive association between both income and mother's year of education and the child's PPVT-III score.

After controlling for context, in addition to customary controls for socioeconomic advantage, and parental mediation of media use, the amount of time spent with media is not significantly associated with receptive vocabulary at this stage of the child's development. This is a noteworthy given the convention of paediatric advice on limiting television in the child's early years (American Academy of Pediatrics, 2010). ${ }^{i}$ Our findings indicate that among pre-schoolers, perhaps, any dose of media is safe provided the protective factors - a stimulating home environment provided by sufficient family income, combined with interactive demonstration of vocabulary associated with high stocks of social capital and, importantly, a supportive parental context for the use of media (especially television) are all in place. This implies the children most at risk of delayed language acquisition those from low socio-economic backgrounds whose parents are not involved in their child's use of media. 
Table 1: 2003 cohort PPVT-III

\begin{tabular}{|c|c|c|c|c|}
\hline Variable & Coefficient & SE & \multicolumn{2}{|c|}{ P-value } \\
\hline \multicolumn{5}{|l|}{ Child has ... (Wave 2.5) } \\
\hline Television in bedroom & -1.172 & 0.415 & 0.005 & \\
\hline Computer in bedroom & -1.160 & 0.794 & 0.145 & \\
\hline Computer in home & 0.507 & 0.435 & 0.244 & \\
\hline Internet in home & 1.408 & 0.424 & 0.001 & \\
\hline Electronic games system & & & & 0.139 \\
\hline Yes & 0.097 & 0.378 & 0.797 & \\
\hline Missing & 0.811 & 0.421 & 0.055 & \\
\hline $\begin{array}{l}\text { Parental mediation (Wave 2.5) } \\
\text { Study child turns television \& dvd on } \\
\text { by themselves } \\
\text { Is television on while no-one is } \\
\text { watching? }\end{array}$ & $\begin{array}{l}-0.311 \\
-1.015\end{array}$ & $\begin{array}{l}0.282 \\
0.373\end{array}$ & $\begin{array}{l}0.271 \\
0.007\end{array}$ & \\
\hline \multicolumn{4}{|c|}{ How easy is it to manage child's use of electronic/computer games } & 0.191 \\
\hline Easy/very easy & 2.001 & 1.124 & 0.076 & \\
\hline N/A & 1.834 & 1.130 & 0.106 & \\
\hline Watch programs with child & 0.535 & 0.254 & 0.036 & \\
\hline \multicolumn{5}{|l|}{ Patterns of media use (Waves 1 to 3 ) } \\
\hline Television viewing & & & & 0.583 \\
\hline Mixed & -0.338 & 0.340 & 0.321 & \\
\hline High consistent use & -0.162 & 0.481 & 0.737 & \\
\hline \multicolumn{5}{|l|}{ Reading } \\
\hline Mixed use & 0.950 & 0.386 & 0.014 & 0.005 \\
\hline High consistent use & 1.731 & 0.532 & 0.001 & \\
\hline \multicolumn{5}{|l|}{ Control variables (Wave 1) } \\
\hline $\begin{array}{l}\text { Mothers education years } \\
\text { Equivalised household income (\$AU }\end{array}$ & 0.185 & 0.052 & $<0.001$ & \\
\hline 10,000$)$ & 0.456 & 0.081 & $<0.001$ & \\
\hline Intercept & 57.682 & 1.536 & $<0.001$ & \\
\hline
\end{tabular}

As Table 2 shows, factors affecting language acquisition, as measured by receptive vocabulary, remain remarkably similar as the child matures. For the 1999 birth cohort at age 8 years, family resources, time spent in using print media and the parental context of the child's media use continue to be significantly related the to child's mastery of vocabulary, and effects sizes are broadly similar. A TV in the child's bedroom predicts 1 point decline PPVT score for both cohorts when the other influences are held constant. Similarly, each extra year that the child's mother spent in education increases the child's PPVT score by about 0.2 points in both cohorts, while a $\$ 10,000$ increase in annual household income (adjusted 
for family size) is associated with an increase of between 0.3 and 0.4 in PPVT scores for each cohort. Conversely, time spent reading has a much more powerful effect in the early years. In the older cohort only a sustained pattern of time devoted to reading significantly affects PPVT score at age 8 , and the effect is slightly smaller.

For this cohort the only measure of child viewing context was presence of television in the child's bedroom (other questions were not asked). Bedroom-TV remains negatively associated with vocabulary $(\mathrm{P}<.0005)$. Conspicuously, among the older cohort having a computer in the home (Pvalue $<0.05$ ) is significantly associated with a better mastery of vocabulary at age 8 years, although internet connectivity is not significant.

Consistently higher time spent in computer use does not, in itself, improve receptive vocabulary. Nevertheless, our findings suggest that at certain stages of the child's development there is an association between improved language and computer access.

Interestingly, exposure to the much-maligned older media, television, as measured by child's time spent watching over the three waves, does not appear to be significantly related to vocabulary acquisition, once other influences have been taken into account.

Table 2: 1999 cohort PPVT-III

\begin{tabular}{|c|c|c|c|c|}
\hline \multirow{2}{*}{\multicolumn{5}{|c|}{$\begin{array}{l}\text { Variable } \\
\text { Child has ... (Wave 2.5) }\end{array}$}} \\
\hline & & & & \\
\hline Television in bedroom & -1.144 & 0.296 & 0.000 & \\
\hline Computer in bedroom & -0.009 & 0.312 & 0.976 & \\
\hline Computer in home & 1.643 & 0.686 & 0.017 & \\
\hline Internet in home & -0.607 & 0.560 & 0.280 & \\
\hline Electronic games system & & & & 0.273 \\
\hline Yes & -0.389 & 0.263 & 0.140 & \\
\hline Missing & -0.489 & 0.345 & 0.158 & \\
\hline $\begin{array}{l}\text { Parental Mediation (Wave 2.5) } \\
\text { How easy is it to manage child's use of } \\
\text { electronic/computer games }\end{array}$ & & & & 0.937 \\
\hline Easy/very easy & -0.081 & 0.427 & 0.849 & \\
\hline $\begin{array}{l}\text { Missing } \\
\text { Parent wishes child would spend less } \\
\text { time }\end{array}$ & -0.256 & 0.720 & 0.722 & \\
\hline watching television & 0.328 & 0.282 & 0.247 & \\
\hline
\end{tabular}




\begin{tabular}{lllll}
$\begin{array}{l}\text { Patterns of media use (Waves 1 to 3) } \\
\quad \text { Television }\end{array}$ & & & & \\
$\quad \begin{array}{l}\text { Mixed } \\
\quad \text { Consistently high }\end{array}$ & -0.431 & 0.312 & 0.168 & 0.387 \\
$\begin{array}{l}\text { Computer } \\
\quad \text { Mixed }\end{array}$ & -0.408 & 0.457 & 0.373 & \\
$\quad$ Consistently high & 0.505 & 0.257 & 0.051 & 0.136 \\
$\begin{array}{l}\text { Reading } \\
\quad \text { Mixed }\end{array}$ & 0.326 & 0.416 & 0.434 & \\
$\quad$ Consistently high & 0.283 & 0.375 & 0.450 & 0.023 \\
$\begin{array}{l}\text { Controls } \\
\text { Mothers education years (Wave 1) }\end{array}$ & 1.317 & 0.524 & 0.013 & \\
$\begin{array}{l}\text { Equivalised household income (\$AU } \\
\text { 10,000) }\end{array}$ & 0.207 & 0.046 & $<0.001$ & \\
Intercept & 0.326 & 0.077 & $<0.001$ & \\
\hline
\end{tabular}

PPVT-III is a measure of verbal abilities in vocabulary and not literacy in the broader sense outlined earlier in the paper. However, teacher ratings (ARS) assess extra dimensions of traditional and ICT literacy as well.

Table 3 shows that, at age 8 years, the results for this broader measure of literacy closely resemble those for Peabody measure of receptive vocabulary. Parental socio-economic capitals have significant (Pvalue $<0.001$ ) association with language acquisition and literacy. In contrast to children with a history of consistent low time spent in reading, those with a history of mixed or consistently high time spent reading have higher language and literacy scores. The improvement in the scores is monotonic. The effect size of a pattern of consistently high time spent in reading over the four-year period is almost $50 \%$ higher than effect size for the children with a mixed pattern of reading.

The subtle differences between results for Table 2 and Table 3 centre on reduced significance of access (and perhaps parent mediation of media use) and the significant and substantial positive association of ARS and consistent computer use. Whether the computer is in the child's bedroom or the home or has an internet connection has no effect on the teacher's rating of the child's language and literacy when time spent in computer use and other independent variables are held constant. Similarly, there is 
no significant net effect on ARS scores for the 8-year-old children having a television in their bedroom. However there is a significant effect $(\mathrm{P}-$ value $<0.05$ ) of having a games console (or functionally similar device) in the house.

Perhaps the most striking feature of Table 3 is the positive $(\mathrm{P}$-value $<0.05)$ relationship between time devoted to computer use between ages 4-8 years and improved all-around literacy, as measured by the ARS scores. While effect size for continuous access to computers is roughly half that of continuous exposure to reading, the increase associated with a continuously high level of computer use compared to mixed use are proportionally the same. Moreover, the effects of access to computers (but perhaps not solely for the purpose of playing electronic games) go in the opposite direction from the alleged effects of sustained exposure to television, while the opposite holds true of access to electronic games.

These findings also suggest that if children devote anything other than the lowest time to reading or computer use, over the 4 years, regardless of amount of time devoted to television, their literacy in the early years of schooling will be advanced.

Table 3: 1999 Cohort Language and Literacy Academic Rating Score

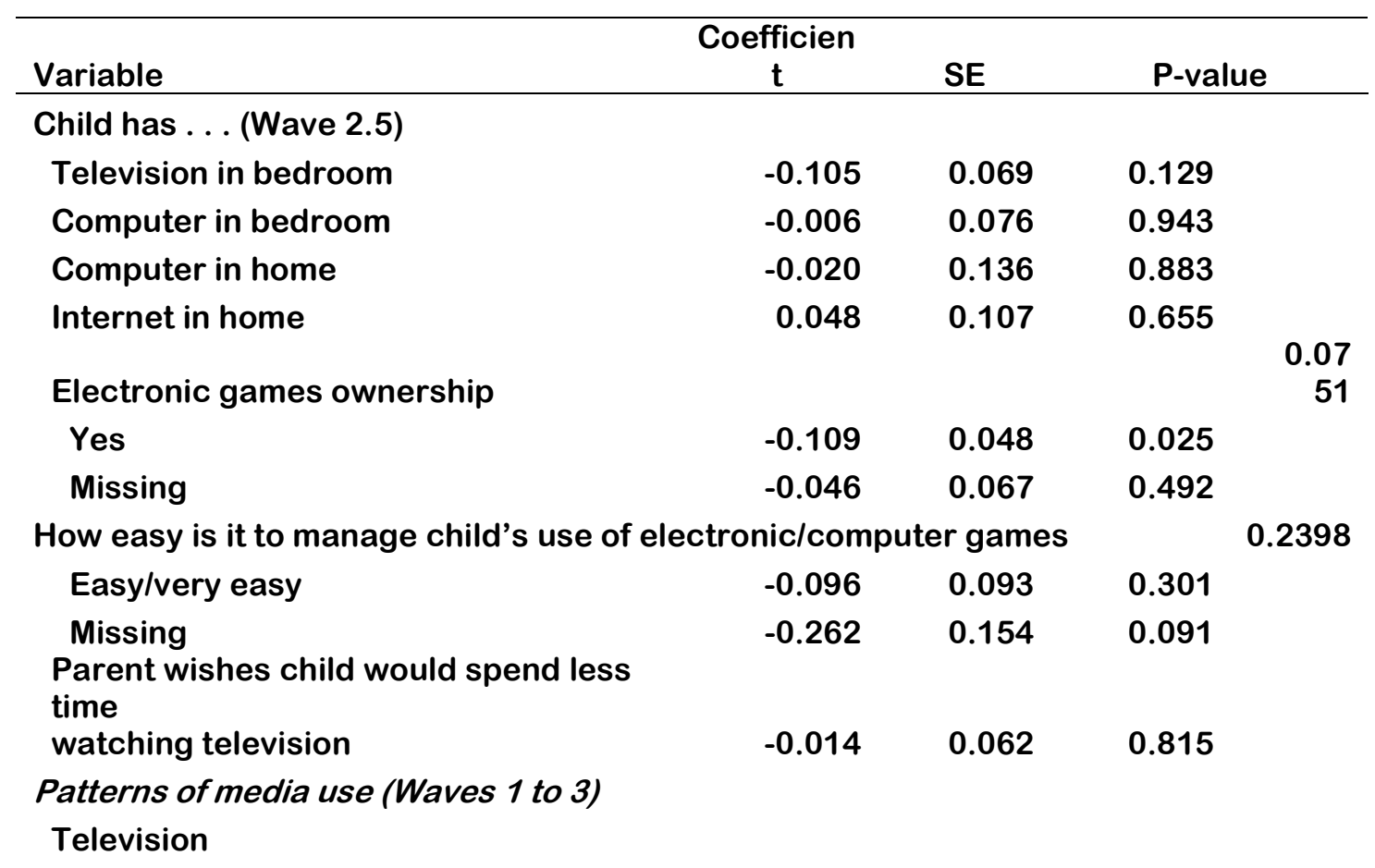




\begin{tabular}{|c|c|c|c|c|}
\hline & & & & 0.137 \\
\hline Mixed & -0.103 & 0.063 & 0.103 & 8 \\
\hline High consistent & -0.193 & 0.100 & 0.054 & \\
\hline \multicolumn{5}{|l|}{ Computer } \\
\hline & & & & 0.012 \\
\hline Mixed & 0.161 & 0.060 & 0.007 & 4 \\
\hline High consistent & 0.208 & 0.078 & 0.008 & \\
\hline \multicolumn{5}{|l|}{ Reading } \\
\hline & & & & $<0.00$ \\
\hline Mixed & 0.285 & 0.067 & 0.000 & 1 \\
\hline High consistent & 0.418 & 0.096 & $<0.001$ & \\
\hline \multicolumn{5}{|l|}{ Control variables (Wave 1) } \\
\hline $\begin{array}{l}\text { Mothers education years } \\
\text { Equivalised household income (\$AU }\end{array}$ & 0.036 & 0.010 & 0.001 & \\
\hline 10,000$)$ & 0.055 & 0.015 & $<0.001$ & \\
\hline Intercept & 2.945 & 0.222 & $<0.001$ & \\
\hline
\end{tabular}

\section{Conclusions}

Our results indicate that parents' characteristics and the context that they create for the child's media use in the early years (0-4) have more influence on the child's acquisition of vocabulary than raw "exposure" to television, ${ }^{\text {iii }}$ or the supposedly transformative new media environment prophesized by the "digital natives" thesis. Indeed, our findings point to the significance of the context of viewing and the parent's role ("digital immigrant") in negotiating media with the child. Attention should be paid to encouraging the child's use of the oldest media of all-print-as this is closely associated with receptive vocabulary at age 4 years. Similarly among children 4-8 years, there appears to be no developmental advantage in avoiding exposure to television. Parents' socio-economic resources and time devoted to reading and/or using a computer (over the previous 4 years) are all associated with more advanced abilities with language, comprehension and literacy.

Conversely, providing partial refutation of the idea that gamesmultimedia-based resources are preferably to text-based, ownership of games consoles and functional equivalents is associated with lower linguistic abilities. In contrast to the conventional image of time spent in television displacing activities which promote literacy, it seems that 
computer use and print literacy (but not electronic games) are synergistic activities, that each promotes the development of the other.

Taken together these findings are consistent with the idea that there may be distinct developmental stages in the ability to use digital devices. Firstly, our data indicates that use of computers in infancy appears to be negligible and therefore plays no part in explaining the development of receptive vocabulary. ${ }^{\text {iv }}$ Second, the growth of vocabulary as the child develops appears to be unaffected by old electronic media and more by the parents' education and participation in their child's media use. Third, computer (but not games) use at later ages seems associated with increased traditional literacy. The timing of the effect of computers suggests a developmental sequence-that certain levels of linguistic capacity are necessary to facilitate use of this platform.

This pattern seems consistent with Vygotsky's (1987) scaffolding theory of learning. Even co-viewing television with parents seems to promote verbal abilities, especially when parents have significant social capital and material resources available to transfer. Our results raise the intriguing prospect that it is not "exposure" to media that harms language acquisition and development of traditional literacy but the absence of age-appropriate, "guided interaction" (Plowman, et. al., 2008) by parents. Although not directly measured in this study, it may be that instructional scaffolding is important in the process of increased digital literacy as well.

\section{References}

American Academy of Pediatrics (2010). Where we stand: TV viewing time. Retrieved from http://www.healthychildren.org/English/family-life/workplay/Media/Pages/Where-We-Stand-TV-Viewing-Time.aspx

Anderson, D. and Pempek, T, (2005). Television and very young children. American Behavioural Scientist 48(5), 505-522.

Anderson, R.C., Wilson, P. T., and Fielding, L. G. (1988) Growth in reading and how children spend their time outside of school. Reading Research Quarterly 23(3), 285-303. 
Anderson, D, Huston, A, Schmitt, K, Linebarger, D and Wright, J (2001). Early childhood television viewing and adolescent behaviour: The recontact study. Monographs of the Society for Research in Child Development 66(1), 1-143.

Anderson, D. and Hanson, K. (2010) From blooming, buzzing confusion to media literacy: The early development of television viewing. Developmental Review 30: 239-255.

Bennett, S., Maton, K., and Kervin, L. (2008). The "digital natives" debate: A critical review of the evidence. British Journal of Educational Technology 39(5), 775-786.

Baxter, J. and Hayes, A. (2007). How four-year-olds spend their days: Insights into the caring context of young children. Family Matters 76: 34-43.

Bianchi, S. and Robinson, J. (1997). What did you do today? Children's use of time, family composition, and the acquisition of social capital. Journal of Marriage and Family 59(2), 332-344.

Bickham, D., Wright, J. and Huston, C. (2001). Attention, comprehension and the educational influences of television. In D. Singer and J. Singer (Eds.). Handbook of Children and the Media (pp. 101-119). Sage: Thousand Oaks, CA.

Bourdieu, P. (1986). The forms of capital. In J.G. Richardson (Ed.) Handbook of Theory and Research for the Sociology of Education (pp. 241-258). New York: Greenwood Press.

Buckingham, D. (2006). Is there a digital generation? In D. Buckingham and R. Willett (Eds.) Digital Generations: Children, young people and new media (pp. 1-13). Mahwah, NJ: Lawrence Erlbaum Associates.

Coiro, J., Knobel, M., Lankshear, C., and Leu, D. (Eds.) (2008). Handbook of research on new literacies. New York: Routledge.

Cope, B., and Kalantzis, M. (Eds.) (2000). Multiliteracies: Literacy learning and the design of social futures. New York: Routledge.

Dede, C. (2005). Planning for neomillenial learning styles: Implications for investments in faculty and technology. In D. Oblinger and J. Oblinger (Eds.) Educating the net generation. Retrieved from http://www.educause.edu/PlanningforNeomillennialLearningStyles\%3AImpli cationsforInvestmentsinTechnologyandFaculty/6069

Duncan, G.J. and Brooks-Gunn, J. (Eds.) (1997). Consequences of growing up poor. New York: Russell Sage.

Foehr, U. (2006) Media multitasking among American youth. Menlo Park: Kaiser Family Foundation.

Garrett P, Ng'andu N and Ferron J. (1994). Poverty experiences of young children and the quality of their home environments. Child Development 65(2), 331 345 .

Gee, J. P. (2003). What video games have to teach us about learning and literacy? London: Palgrave/Macmillan. 
Hague, C. and Williamson, B. (2009). Digital participation, digital literacy, and school subjects: A review of the policies, literature and evidence. Retrieved from

http://www.futurelab.org.uk/resources/documents/lit_reviews/DigitalPartici pation.pdf

Hancox, R.J., Milne B.J., and Poulton, R. (2005). Association of television viewing during childhood with poor educational achievement. Archives Pediatrics and Adolescent Medicine 159(7), 614-618.

Helsper, E., and Eynon, J. (2010). Digital natives: where is the evidence? British Educational Research Journal 36(3), 503-520.

Hofferth, S. and Sandberg, J. (2001). How American children spend their time. Journal of Marriage and Family 63(2), 295-308.

Howe, N., \& Strauss, W. (2000). Millenials rising: The next great generation. New York: Vintage.

Jackson, L., Von Eye, A., Biocca, F., Barbatsis, G., Zhao, Y. \& Fitzgerald, H. (2006). Children's home internet use: Antecedents and psychological, social and academic consequences. In R. Kraut, M. Brynin \& S. Kiesler (Eds.), Computers, phones, and the internet: Domesticating information technology (pp. 145-67). Oxford: OUP.

Jenkins, H. (2006) Convergence culture: Where old and new media collide. New York: NYU Press.

Jenkins, H. (2007) Reconsidering digital immigrants. Retrieved from http://www.henryjenkins.org/2007/12/reconsidering_digital_immigrants.htm 1

Kirkorian, H., Wartella, E. and Anderson, D. (2008). Media and young children's learning. The Future of Children 18(1), 39-61.

Kress, G. (2003). Literacy in the new media age. New York: Routledge.

Lenhart, A., Madden, M., and Hitlin, P.(2005). Teens and technology: Youth leading the transition to a fully wired and mobile nation. Washington, DC: Pew Internet and American Life Project.

Linebarger, D. and Vaala, S. (2010). Screen media and language development in infants and toddlers: An ecological perspective. Developmental Review 30, 176-202.

Livingstone, S. (2002). Young people and new media. London: Sage.

Manovich, L. (2003) New media from Borges to html. In N. Wardrip-Fruin \& N. Montfort (Eds.) The New Media Reader (pp. 13-25). Cambridge, MA: MIT Press.

Martin, A. and Madigan, D. (Eds.) (2006). Digital literacies for learning. London: Facet

Millwood Hargrave, A. and Livingstone, S. (2006). Harm and offence in media content: A review of the evidence, Bristol, UK: Intellect. 
Moreno, R., and Mayer, R.E. (2005). Role of guidance, reflection and interactivity in an agent-based multimedia game. Journal of Educational Psychology 97(1), 117-128.

Newman, T. (2008). A Review of digital literacy in 3-16 year olds: Evidence, developmental models, and recommendations. London: Timmus.

Paavonen, E., Pennonen, M., Roine, M., Valkonen, S. \& Lahikainen, A. (2006). TV exposure associated with sleep disturbances in 5- to 6-year-old children. Journal of Sleep Research 15(2), 154-161.

Plowman, L., McPake, J. \& Stephen, C. (2008). Just picking it up? Young children learning with technology at home. Cambridge Journal of Education 38(3), 303-319.

Prensky, M. (2001). Digital natives, digital immigrants. On the Horizon, 9(5), 1-6.

Rideout, V. and Hamel, E. (2006). The media family: Electronic media in the lives of infants, toddlers, preschoolers and their parents. Menlo Park: Kaiser Family Foundation.

Roberts, D. and Foehr, U. (2008). Trends in media use. The Future of Children 18(1), 11-37.

Roberts, D., Foehr, U., and Rideout, V. (2005). Generation M: Media in the lives of 8-18 year olds. Menlo Park, CA: Kaiser Family Foundation.

Robinson, J., \& Martin, S. (2010). IT use and declining social capital?: More cold water from the General Social Survey (GSS) and the American Time-Use Survey (ATUS). Social Science Computer Review 28(1), 45-63.

Rowe M.L, Pan, B.A. and Ayoub, C. (2005). Predictors of variation in maternal talk to children: A longitudinal study of low-income families. Parenting: Science and Practice 5(3), 259-283.

Rubinstein, J., Meyer, D.E. \& Evans, J.E. (2001). Executive control of cognitive processes in task switching. Journal of Experimental Psychology: Human Perception and Performance 27(4), 763-797.

Schmidt, M. \& Anderson, D. (2007). The impact of television on cognitive development and educational achievement. In N. Pecora, J. Murray \& E. Wartella (Eds.) Children and Television: Fifty Years of Research (pp. 65-84). Mahwah, New Jersey: Lawrence Erlbaum.

Schmidt, M., Rich, M., Rifas-Shiman, S., Oken, E., Taveras, E. (2009). Television viewing in infancy and child cognition at 3 years of age in a US cohort. Pediatrics 123(3), e370-e375

Schmidt, M. \& Vandewater, E. (2008). Media and attention, cognition, and school achievement. The Future of Children 18(1), 63-85.

Sharif, I. \& Sargeant, J. (2006). Association between television, movie, and video game exposure and school performance. Pediatrics 118(4), el061-70.

Silverstone, R. (1999). New media, new audiences? New Media \& Society 1(1), 1012 
Copyright 2011 A ustralian Council for Educational Research. T his article may not exactly replicate the final version published in A ustralian Journal of Education. It is not a copy of the record. Final and authorised version first published in A ustralian Journal of Education in Vol. 55(2), published by the A ustralian Council for Educational Research.

Sipthorp, M. and Misson, S. (2009). Wave 3 weighting and non-response (LSAC technical paper no. 6). Melbourne: Australian Institute of Family Studies

Soloff, C., Lawrence, D., \& Johnstone, R. (2005). Sample Design (LSAC Technical Paper No.1), Growing up in Australia: the Longitudinal Study of Australian Children. Melbourne: Australian Institute of Family Studies.

Soloff, C., Lawrence, D., Misson, S., \& Johnstone, R. (2006). Wave 1 weighting and non-response (LSAC Technical Paper No 3). Melbourne: Australian Institute of Family Studies.

Spigel, L., and Olsson, J. (Eds.) (2004) Television after TV: Essays on a medium in transition. Durham: Duke University Press.

Tapscott, D. (1998). Growing up digital: The rise of the net generation. New York: McGraw-Hill.

Vandewater, E. A., Bickham, D.S., Lee, J.H., Cummings, H.M., Wartella, E.A., and Rideout, V.J. (2005). When the television is always on: Heavy television exposure and young children's development. American Behavioral Scientist 48(5), 562-577.

Vygotsky, L. S. (1987). Thinking and speech. In R. Rieber \& A. Carton, (Eds.) L. S. Vygotsky, Collected Works Vol. 1 (N. Minick, Trans., pp.39-285). New York: Plenum.

Wiecha, J.L., Sobol, A.M., Peterson, K.E. and Gortmaker, S. L. (2001). Household television access: Associations with screen time, reading, and homework among youth. Ambulatory Pediatrics 1(5), $244-251$.

Wright, J.C., Huston, A.C., Murphy, K.C., St. Peters, M., Piñon, M., Scantin, R. and Kotler, J. (2001). The relations of early television viewing to school readiness and vocabulary of children from low-income families: The early window project. Child Development 72(5), 1347-1366.

\footnotetext{
' It may be that the American Academy of Pediatrics has over-interpreted the literature which contains inconsistent findings on this issue (Schmidt et al., 2009; Sharif \& Sargeant, 2006; Schmidt \& Vandewater, 2008).

${ }^{\text {ii }}$ Sensitivity testing showed that omitting the item "uses the computer" does not reduce the significance of association between computer use and ARS.

iii It may be that children with a television in their own bedroom spend more time watching television without their parents' knowledge, thus equating with having the television on at all times, and is indicative of parental boundary-setting as well as "exposure time".

iv However, their parent's use of the internet does seem to be positively related to the child's acquisition of vocabulary.
} 